\section{Geochemical variation of the Central EI Negrillar volcanic cluster: in the midst of one of the largest monogenetic fields in the Central Andes, Chile.}

DANIELA PARRA ${ }^{1,2}$, DR. PATRICIA LARREA, PHD ${ }^{2,3}$, BENIGNO GODOY ${ }^{2}$ AND PETRUS LE ROUX ${ }^{4}$

${ }^{1}$ Department of Geology, Facultad de Ciencias Físicas y

Matemáticas, Universidad de Chile

${ }^{2}$ Centro de Excelencia en Geotermia de los Andes (CEGA), Universidad de Chile

${ }^{3}$ Departamento de Geología, Facultad de Ciencias Físicas y

Matemáticas, Universidad de Chile

${ }^{4}$ University of Cape Town

Presenting Author: danielaparraencalada@gmail.com

El Negrillar is one of the largest monogenetic volcanic fields of the Central Volcanic Zone (CVZ) located at the southern limit of the Altiplano Puna Volcanic Complex, Chile. This volcanic field is comprised of more than 25 eruptive centers distributed over $\sim 168 \mathrm{~km}^{2}$, and it is spatially divided into three clusters: Northern El Negrillar, Central El Negrillar (CEN) and Southern El Negrillar.

The present study focuses on the geochemical variation of the 10 volcanoes comprising the CEN cluster. Their lava flows mainly range from andesites to dacites with a few trachydacites, with 57.05-65.43 wt.\% $\mathrm{SiO}_{2}$ and 5.60-7.28 wt.\% $\mathrm{Na}_{2} \mathrm{O}+\mathrm{K}_{2} \mathrm{O}$ contents. Major element bivariate plots exhibit a decrease in $\mathrm{FeO}^{\mathrm{T}}$ (3.7-7.0 wt.\%), $\mathrm{MgO}$ (1.9-5.8 wt.\%), $\mathrm{TiO}_{2}$ (0.71-1.27 wt.\%), $\mathrm{CaO}$ (4.08-7.34 wt.\%) and $\mathrm{P}_{2} \mathrm{O}_{5}\left(0.25-0.49\right.$ wt.\%) as $\mathrm{SiO}_{2}$ increases. $\mathrm{Al}_{2} \mathrm{O}_{3}$ (16.34-17.01 wt.\%) and $\mathrm{Na}_{2} \mathrm{O}$ (4.15-4.55 wt.\%) contents do not show a well-defined trend with increasing $\mathrm{SiO}_{2}$, whereas $\mathrm{K}_{2} \mathrm{O}$ (1.43-2.82 wt.\%) shows an increase with increasing $\mathrm{SiO}_{2}$. Remarkably, Negro volcano, with the largest number of lava flows emitted (6), shows a $\mathrm{MgO}$ variation of less than 2 wt.\% and it is not possible to establish a pattern in the $\mathrm{P}_{2} \mathrm{O}_{5}$ content.

Trace element abundances also correlate with $\mathrm{SiO}_{2}$ content, however, these volcanic centers exhibit relatively lower Ni (18$60 \mathrm{ppm}), \mathrm{Sc}(6-18 \mathrm{ppm})$ and $\mathrm{Cr}(20-120 \mathrm{ppm})$ concentrations than other mafic monogenetic eruptive centers from the CVZ (e.g., Cerro Overo [1], Cerro Tujle, El País, and North \& South Tilocar [2]). The only exception is the oldest volcano of the CEN cluster (Cola de Caballo), which shows the lowest $\mathrm{SiO}_{2}$ (57.05 wt.\%) and highest $\mathrm{Ni}(121 \mathrm{ppm})$ contents. Incompatible elements such as $\mathrm{Ba}, \mathrm{La}, \mathrm{Sr}$ and $\mathrm{Rb}$ show positive correlations with the increase of $\mathrm{SiO}_{2}$ and their high concentrations stand out with respect to the other mafic centers named above. A multielemental diagram normalized to N-MORB shows LREE enrichment and HREE depletion, which are in any case significantly lower than similar patterns in the other mafic volcanoes of the CVZ.

[1] González-Maurel, Godoy, le Roux, Rodríguez, Marín, Menzies, Bertín, Morata \& Vargas (2019). Lithos, 338-339:128- 